\title{
USPOREDBA KONSTRUKCIJSKIH RJEŠENJA KROVNE KONSTRUKCIJE DVORANE U STOBREČU
}

\author{
Goran Ćurković \\ Sveučilište u Splitu, Fakultet građevinarstva, arhitekture i geodezije, student \\ Alen Harapin \\ Sveučilište u Splitu, Fakultet građevinarstva, arhitekture i geodezije, prof.dr.sc.
}

Sažetak: U radu je prikazana usporedba dvaju konstrukcijskih rješenja krova školske sportske dvorane u Stobreču pokraj Splita. Školsku dvoranu se planira nadograditi pokraj postojeće škole, za što je izrađen projekt koji je sada u postupku ishođenja građevinske dozvole. Prema zahtjevima investitora, nad školskom dvoranom se planira izvesti školsko igralište. Na vječno pitanje: „Što je optimalno: beton ili čelik?", pokušali smo dati odgovor kroz ovaj diplomski rad. Napravljena su dva rješenja za rasponsku konstrukciju krova: prednapeti nosač i standardna čelična rešetka koji su opterećeni istim opterećenjem, proračunati i dimenzionirani prema trenutačno važećim propisima.

Ključne riječi: školska sportska dvorana, konstrukcijsko rješenje krova, prednapeti betonski nosač, čelični rešetkasti nosač, analiza cijena gradnje

\section{A COMPARISON OF STRUCTURAL SOLUTIONS OF ROOF OF SCHOOL HALL IN STOBREČ}

Abstract: The paper presents a comparison of two structural solutions for the sports hall roof of primary school in Stobreč near Split. The school sports hall is planned to be built near the existing school building. A design for the school sports hall, which has already been made, is currently in the process of obtaining a building permit. At the request of investors, a school playground is planned to be built on top of the hall roof.

The paper attempts to answer the eternal question: „what is optimum building material: concrete or steel?" For the construction of the hall roof two solutions are presented; pre-stressed girders and standard steel lattice girder, which are burdened with the same load, calculated and dimensioned in accordance with the currently applicable regulations.

Key words: school sports hall, the roof structural solution, prestressed concrete girder, steel truss girder, analysis of construction prices 


\section{Uvod}

Osnovna škola Stobreč nastala je na dijelu strelišta za glinene golubove, izgrađenog za potrebe Mediteranskih igara u Splitu 1979. godine. Škola je izgrađena 1993. godine te su u okviru školskog dvorišta zadržane tribine strelišta do kojih se dolazilo s parkinga na sjevernoj strani parcele (slika 1). Tada je idejnim projektom bila zamišljena dvorana dimenzija 15x30 m koja nije izvedena. Novim projektom [2] predviđena je trodijelna školska dvorana dimenzija 45×27m.
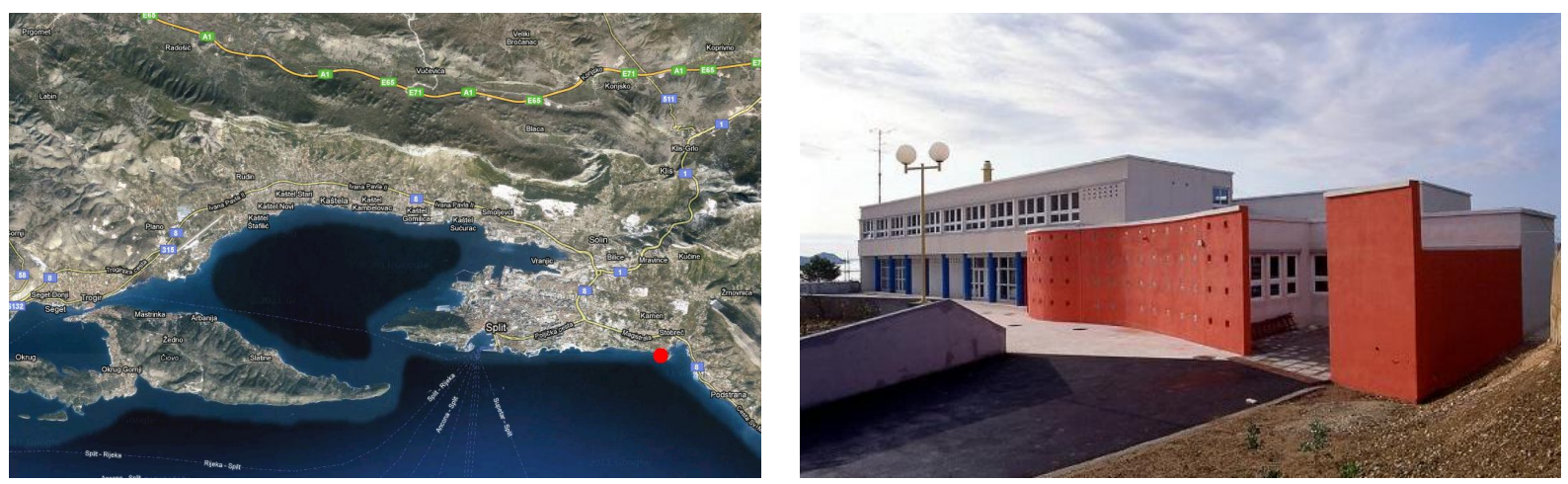

\section{Slika 1 - Geografski položaj građevine (crvena točka) i fotografija sadašnjeg stanja škole}

Škola je smještena na parceli nepravilnog oblika, veličine oko $9200 \mathrm{~m} 2$. Duljina parcele u smjeru istokzapad je cca. $153 \mathrm{~m}$, a u smjeru sjever-jug cca. $88 \mathrm{~m}$, minimalne širine u smjeru sjever-jug cca. $26 \mathrm{~m}$. Sjeveroistočna granica parcele definirana je postojećom gradskom prometnicom s koje su riješeni kolni pristupi. Zapadna granica je pokos u terenu prema višem susjednom terenu, a južna je padina prema moru [2].

Školska zgrada je smještena neposredno uz zapadnu granicu, u smjeru istok-jugoistok. Sjeverno od nje nalazi se školski trg. Uz sjevernu granicu parcele nalazi se parkiralište koje je od školskog trga odvojeno pojasom zelenila. Zelene površine okružuju školsku zgradu sa sjeveroistočne, istočne i južne strane.

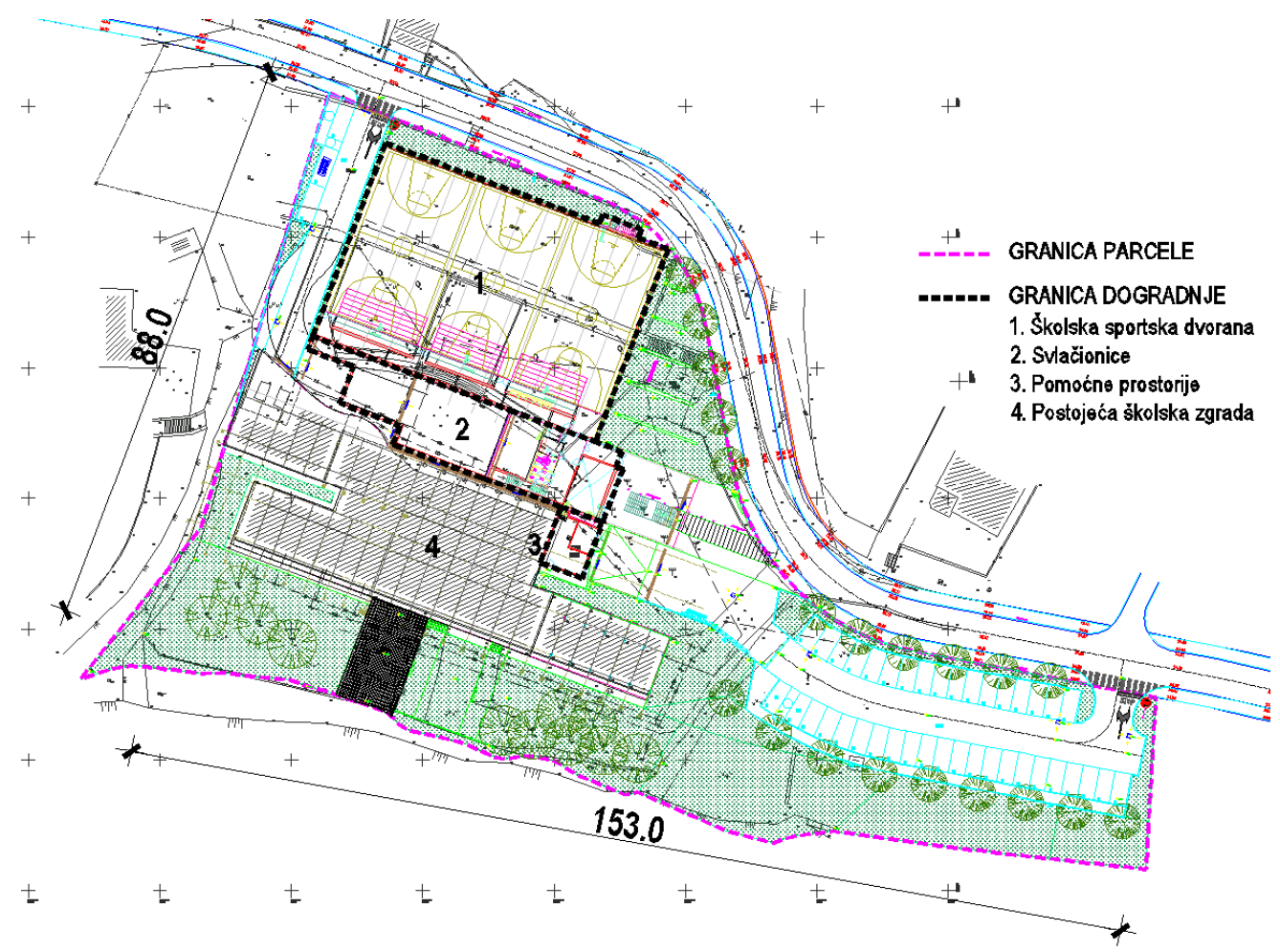

Slika 2 - Situacija građevine (mjere u m) 


\section{Koncepcijsko rješenje krova dvorane}

\subsection{Općenito}

Tlocrt i poprečni presjek dvorane prikazani su na slikama 3 i 4 . Oba predviđena rješenja krovne konstrukcije dvorane također su naznačena na slici 4 . Kako je vidljivo, prvo razmatrano rješenje krovne konstrukcije je rješenje pomoću prednapetih nosača, a drugo rješenje je rješenje čeličnom rešetkom.

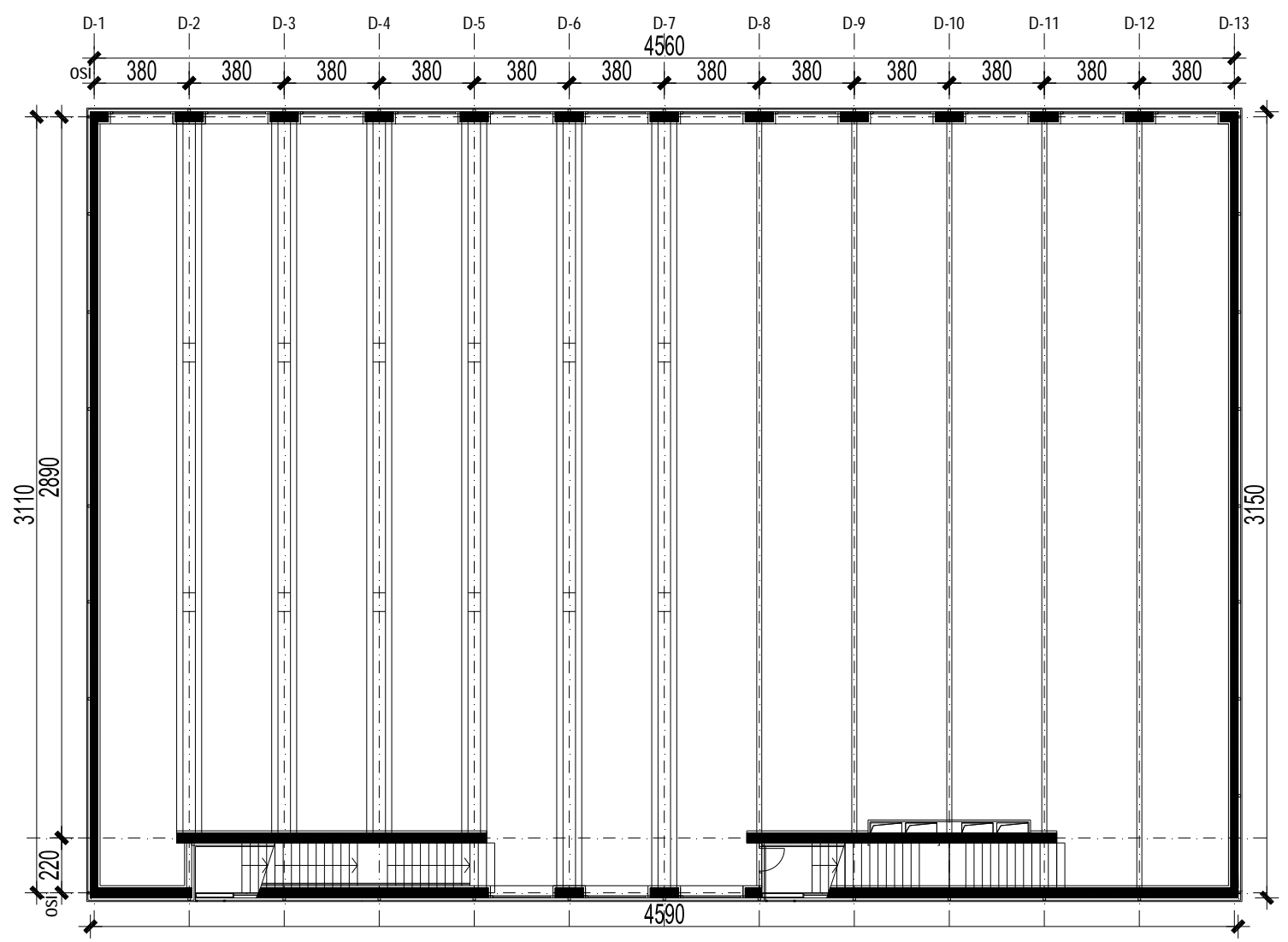

Slika 3 - Tlocrt dvorane s ucrtanim konstrukcijskim sustavom - lijevo prednapeti nosači, desno čelična rešetka (mjere u cm)

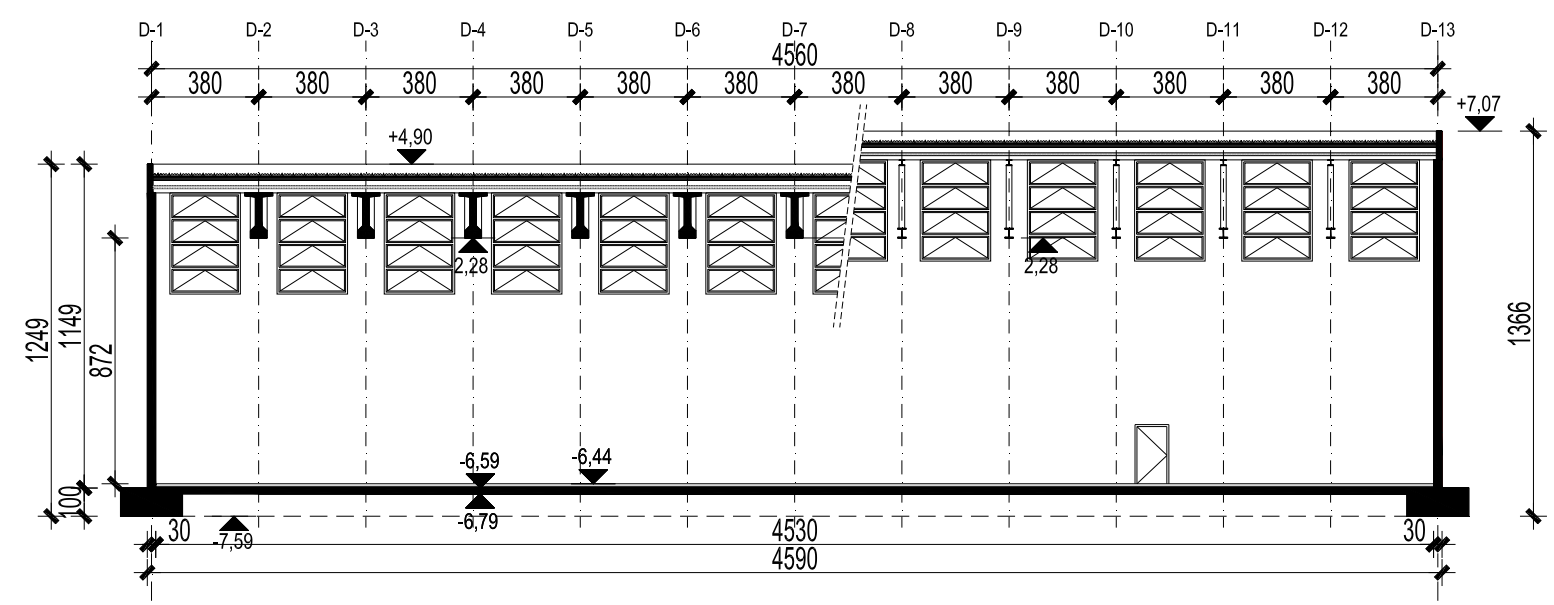

Slika 4 - Poprečni presjek dvorane s ucrtanim konstrukcijskim sustavom - lijevo prednapeti nosači, desno čelična rešetka (mjere $u \mathrm{~cm}$ ) 


\subsection{Rješenje 1 - Prednapeti nosači}

Kod prvog razmatranog rješenja, glavnu nosivu konstrukciju krova dvorane tvore prednapeti montažni krovni nosači $\mathrm{s}$ krovnom pločom. Postoje dva tipa nosača, ukupne duljine 29,1 m i 31,3 m (Slika 12). Nosači su visine $160 \mathrm{~cm}$, a zajedno s krovnom pločom $(\mathrm{d}=15 \mathrm{~cm}) \mathrm{s}$ kojom su spregnuti, ukupna visina krovnih nosača iznosi $175 \mathrm{~cm}$. Širina gornjeg pojasa nosača je $100 \mathrm{~cm}$, a donjeg pojasa $60 \mathrm{~cm}$. Širina hrbata iznosi $24 \mathrm{~cm}$ u polju i $60 \mathrm{~cm}$ nad osloncima.

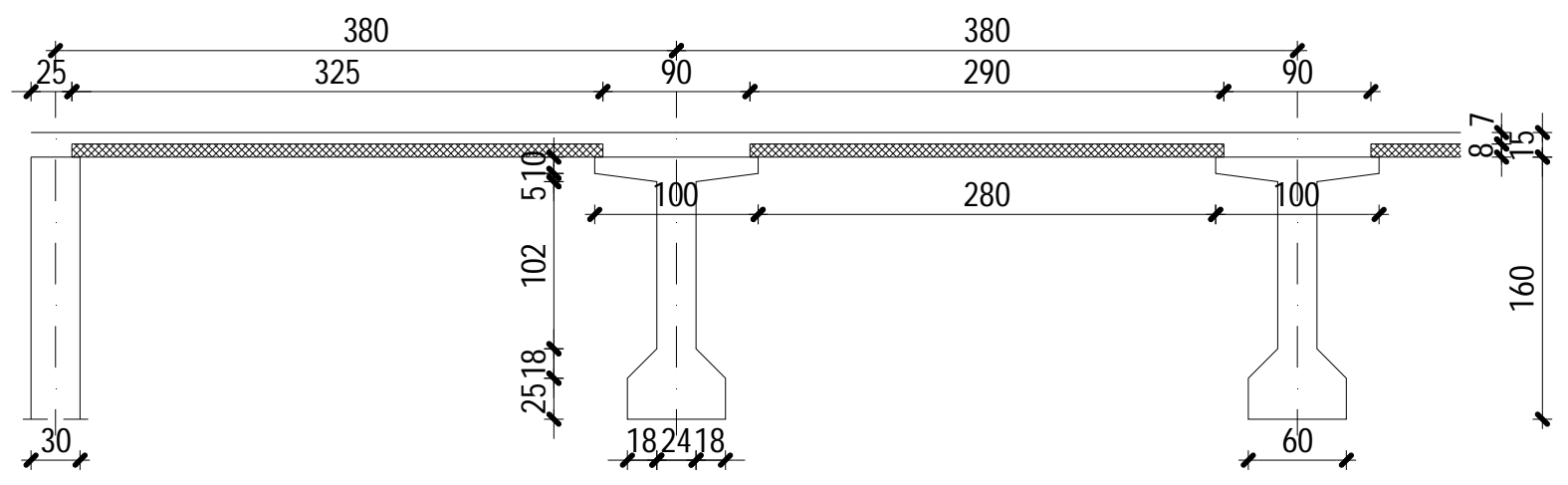

Slika 5 - Poprečni presjek krova kod rješenja s prednapetim nosačima (mjere u cm)

Nosači su predviđeni od betona C 40/50, s agregatom zrna $\leq 31,5 \mathrm{~cm}$. Svi nosači su prednapeti s 3 natege s po 10 užadi. U proračunu je korišten sustav prednapinjanja BBR, što ne umanjuje mogućnost i drugih valjanih sustava prednapinjanja. Korištena je užad promjera 0,62" $\left(A_{u}=150 \mathrm{~mm}^{2}\right)$. Čelik je kvalitete Č 1660/1860. Prednapinjanje nosača se obavlja u jednoj fazi, s oba kraja, kad beton postigne punu čvrstoću i modul elastičnosti (u normalnim uvjetima min. 28 dana).

Krovna ploča izvedena je pomoću „omnia“ ploča, debljine $d=8 \mathrm{~cm}$, koje se u prvoj fazi postavljaju kao slobodno oslonjene ploče na gornje pojasnice prednapetog nosača, a u drugoj fazi kontinuiraju dobetoniravanjem ploče $d=7$ $\mathrm{cm}$. Duljine omnia ploča su $325 \mathrm{~cm}$ u prvom polju i $290 \mathrm{~cm}$ u ostalim poljima.

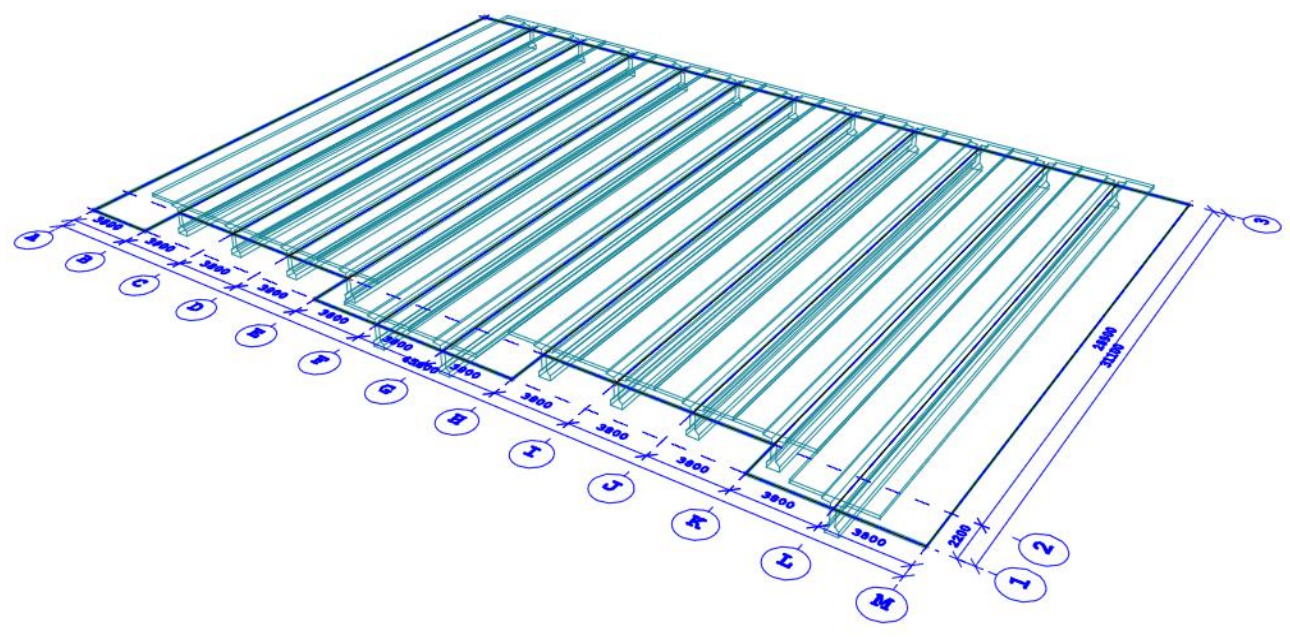

Slika 6 - Proračunski model prednapete krovne konstrukcije

Kako su djelomično prednapeti, nosači su armirani i nenapetom armaturom (betonski čelik B 500B). Predviđeno je da se armatura nastavlja sučelnim zavarom, čija kvaliteta (specijalni zavar) i način kontrole treba u potpunosti biti sukladna važećim propisima i pravilima struke (HRN C.K6.020), a u svemu analogna propisima za nosive čelične konstrukcije.

Nosači na krajevima imaju metalne pločice za sidrenje u zidove prema detaljima u projektu. Na krajevima nosači imaju i bočne „brkove“ (sidra) za vezu sa zidom. Nosači trebaju imati nadvišenje oplate prema projektu. 


\subsection{Rješenje 2 - Čelična rešetka}

Kod drugog razmatranog rješenja, glavnu nosivu konstrukciju krova dvorane tvore čelične rešetke. Također postoje dva tipa rešetki, ukupne duljine 29,1 m i 31,3 m (Slika 16). Rešetka je izrađena iz profila: gornji pojas i ispuna HE 200B i donji pojas HE 340B. Korišten je čelik S235, a pretpostavljeno je potpuno sprezanje rešetkastog nosača S gornjom pločom. Kao i za prednapete nosače, odabrana je gornja ploča debljine $15 \mathrm{~cm}$.

Kao i kod rješenja s prednapetim nosačima, krovna ploča će se izvesti „omnia“ pločama debljine $d=8 \mathrm{~cm}$ koje se u prvoj fazi postavljaju kao slobodno poduprte ploče na gornju pojasnicu čelične rešetke, a u drugoj fazi kontinuiraju dobetoniravanjem ploče $d=7 \mathrm{~cm}$. Duljine omnia ploča u ovom rješenju su nešto veće i iznose $370 \mathrm{~cm}$.

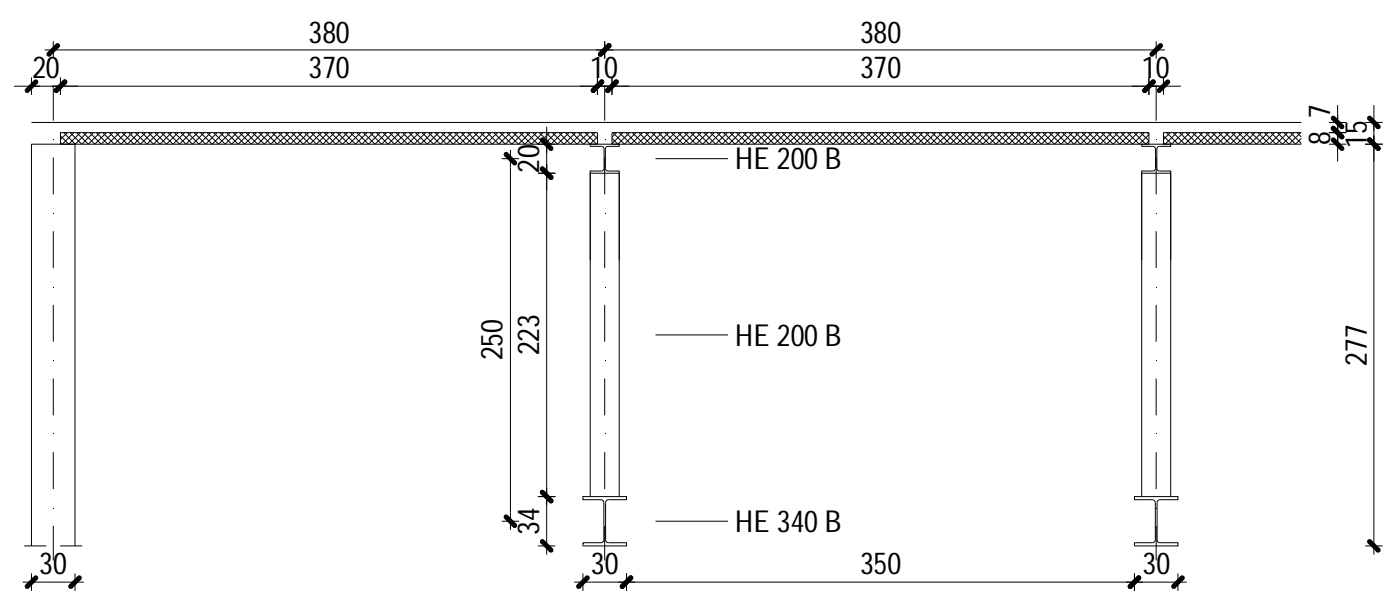

Slika 7 - Poprečni presjek krova kod rješenja s čeličnom rešetkom (mjere u cm)

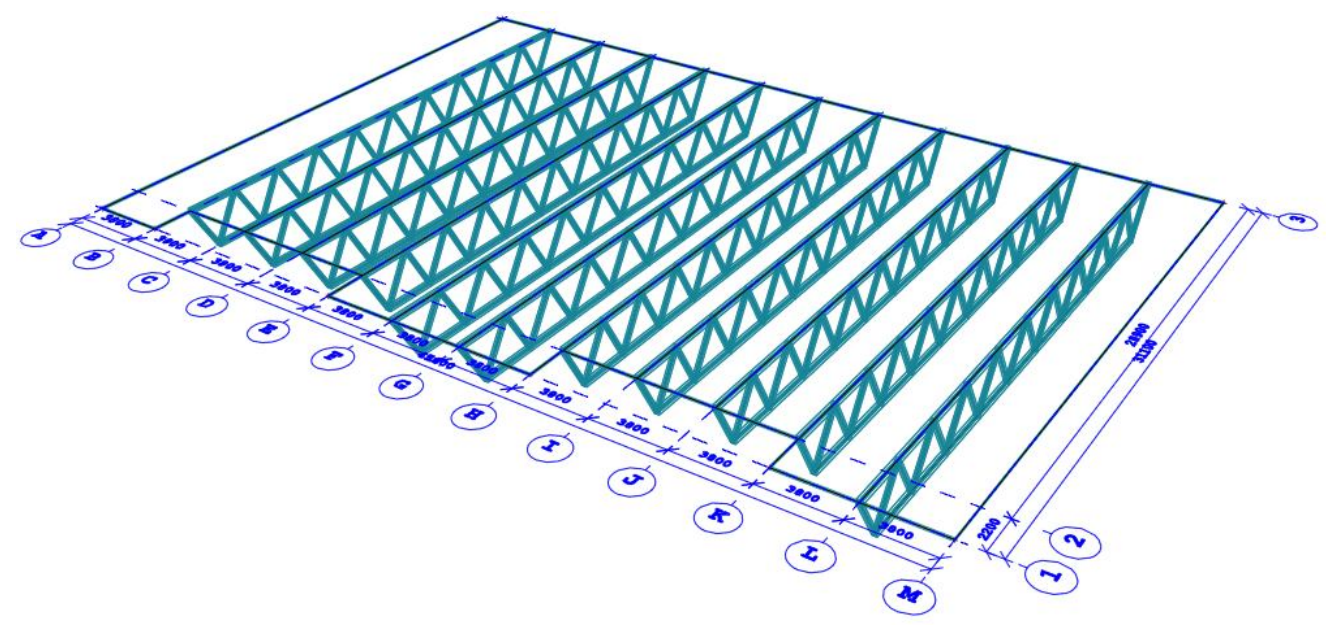

Slika 8 - Proračunski model čelične rešetkaste krovne konstrukcije 


\subsection{Analiza opterećenja}

Krov dvorane opterećen je svojom vlastitom težinom, dodatnim stalnim opterećenjem slojeva igrališta, korisnim opterećenjem na igralištu, te vjetrom i snijegom. Kako je uporabno opterećenje igrališta uzeto u relativno velikom iznosu ( $q=5,0 \mathrm{kN} / \mathrm{m}^{2}$ ), a pretpostavlja se da se igralište neće koristiti u slučaju jakog vjetra ili snijega, kod proračuna i dimenzioniranja se koristilo samo korisno opterećenje. Dodatno stalno opterećenje određeno je iz poprečnog presjeka krova i slojeva krova:

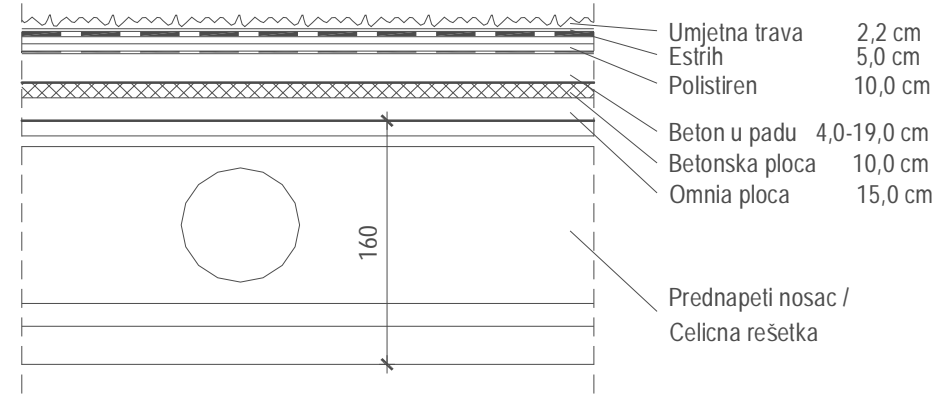

Zadano opterećenje:

\begin{tabular}{|l|r|r|r|}
\hline & $d(\mathrm{~m})$ & $\gamma\left(\mathrm{kN} / \mathrm{m}^{3}\right)$ & $d \times \gamma$ \\
\hline \hline Umjetna trava & & & 0,25 \\
\hline AB estrih & 0,05 & 25,0 & 1,25 \\
\hline Hidroizolacije (ukupno 0.50 cm) & 0,0050 & 20,0 & 0,10 \\
\hline Termoizolacija & 0,10 & 1,0 & 0,10 \\
\hline Beton za pad (prosječno) & 0,12 & 24,0 & 2,90 \\
\hline Instalacije & & & 0,50 \\
\hline
\end{tabular}

\section{Proračun krova dvorane}

\subsection{Proračun omnia ploča}

\subsubsection{Opterećenje}

Proračun omnia ploče je proveden po fazama. U I. fazi ploča je dimenzionirana kao slobodno poduprti nosač odgovarajućeg raspona. U II. fazi ploča je sustava kontinuiranog nosača te je vršen proračun za armaturu u polju i na ležaju. U oba rješenja debljina omnia ploče je $8 \mathrm{~cm}$, a ukupna debljina krovne ploče je $15 \mathrm{~cm}$.

\subsubsection{Omnia ploče nad prednapetim nosačima}

Rezultat proračuna omnia ploča vidljiv je na slici 9 . Za ploče je potrebna mreža R-503 $(08 / 10 \mathrm{~cm})$ koja se u prvom polju dodatno ojačava s po 4 šipke $\varnothing 10$ po svakoj ploči. Odabrana širina omnia ploča je $100 \mathrm{~cm}$. Za gornju zonu ploče odabrana je također armaturna mreža R-503. 


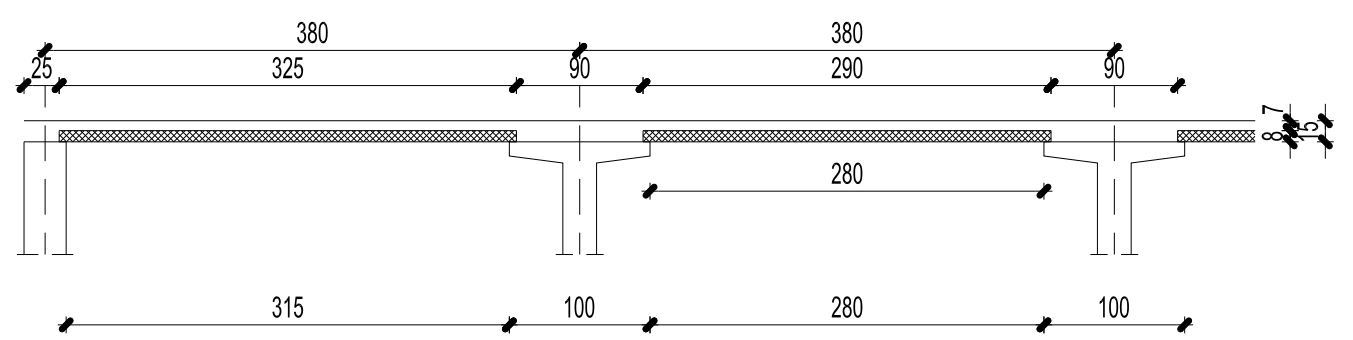

DONJAZONA
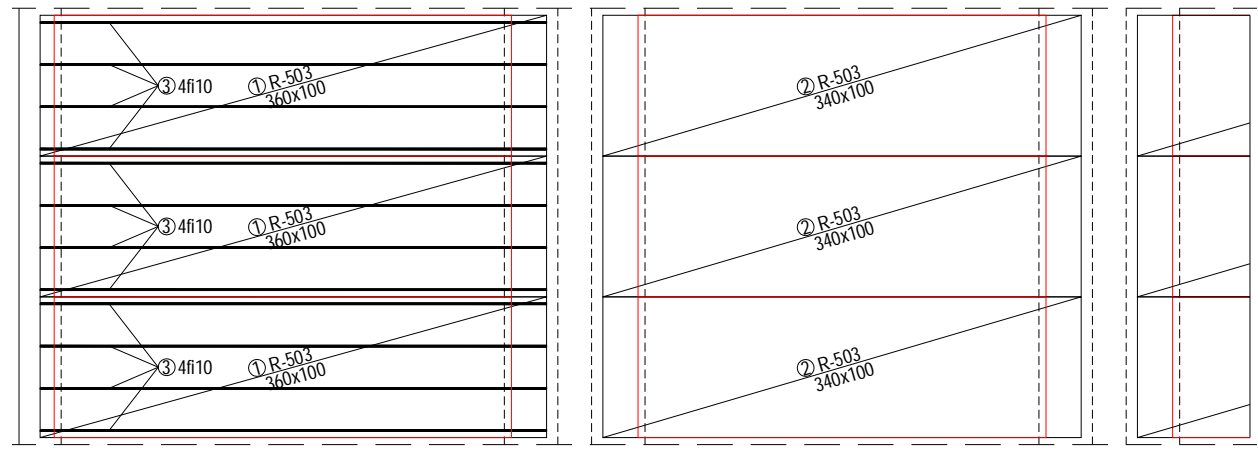

GORNJAZONA

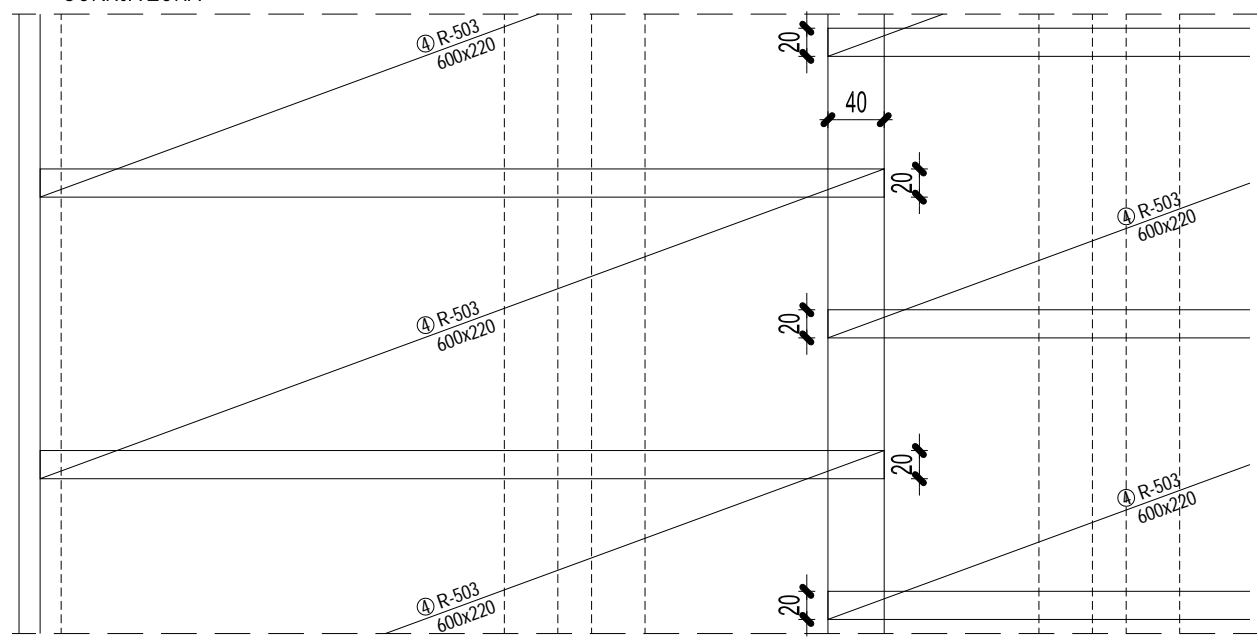

Slika 9 - Odabrana armatura u ploči krova

\subsubsection{Omnia ploče nad čeličnom rešetkom}

Postupak proračuna omnia ploča nad čeličnom rešetkom prikazan je u nastavku. U I. fazi na omnia ploču djeluje njena vlastita težina i težina svježeg betona koji se izlijeva na nju, a u II. fazi omnia ploča i ploča za monolitizaciju djeluju kao jedan nosač opterećen svim ostalim opterećenjima. U I. fazi ploča je dimenzionirana kao prosti nosač raspona 3,6 m. U II. fazi ploča je sustava kontinuiranog nosača te je vršen proračun za armaturu u polju i na ležaju. Debljina omnia ploče je $8 \mathrm{~cm}$, a ukupna debljina krovne ploče iznosi $15 \mathrm{~cm}$ (slika 7). 
Opterećenje u I. fazi:

$\begin{array}{ll}g=0,15 \cdot 25,0=3,75 \mathrm{kN} / \mathrm{m}^{2} & \text { težina omnia ploče } \mathrm{i} \text { težina monolitizacije } \\ \mathrm{q}=1,0 \mathrm{kN} / \mathrm{m}^{2} & \text { uporabno opterećenje u fazi izvedbe }\end{array}$

Opterećenje u II. fazi

$\mathrm{g}=3,75 \mathrm{kN} / \mathrm{m}^{2} \quad$ AB ploča

$\Delta \mathrm{g}=4,6 \mathrm{kN} / \mathrm{m}^{2} \quad$ dodatno stalno opterećenje

$\mathrm{q}=5,0 \mathrm{kN} / \mathrm{m}^{2} \quad$ uporabno opterećenje

\section{I. faza}

$q_{S d}=1,35 \cdot g+1,5 \cdot q=1,35 \cdot 3,75+1,5 \cdot 1,0=6,6 \mathrm{kN} / \mathrm{m}^{2}$

$M_{S d}=\frac{q_{S d} \cdot l^{2}}{8}=\frac{6,6 \cdot 3,6^{2}}{8}=10,7 \mathrm{kNm}$

C 30/37, B 500B

$\mathrm{f}_{\mathrm{cd}}=\mathrm{f}_{\mathrm{ck}} / \gamma_{\mathrm{c}}=30 / 1,5=2,0 \mathrm{kN} / \mathrm{cm}^{2}$

$f_{y d}=f_{y k} / \gamma_{s}=500 / 1,15=43,5 \mathrm{kN} / \mathrm{cm}^{2}$

$$
\begin{aligned}
& \mu_{S d}=\frac{M_{S d}}{b \cdot d^{2} \cdot f_{c d}}=\frac{1070}{100 \cdot 5^{2} \cdot 2,0}=0,214 \\
& \varepsilon_{c 2}=3,1 \% ; \varepsilon_{s 1}=5,0 \% ; \xi=0,383 ; \zeta=0,844 \\
& A_{s 1}^{I}=\frac{M_{S d}}{\zeta \cdot d \cdot f_{y d}}=\frac{1070}{0,844 \cdot 5 \cdot 43,5}=5,83 \mathrm{~cm}^{2} / \mathrm{m}
\end{aligned}
$$

\section{II. faza}

$\begin{array}{ll}\Delta g=4,6 \mathrm{kN} / \mathrm{m}^{2} & \text { dodatno stalno opterećenje } \\ \mathrm{q}=5,0 \mathrm{kN} / \mathrm{m}^{2} & \text { uporabno opterećenje }\end{array}$

$q_{s d}=1,35 \cdot \Delta g+1,5 \cdot q=1,35 \cdot 4,6+1,5 \cdot 5,0=13,7 \mathrm{kN} / \mathrm{m}^{2}$

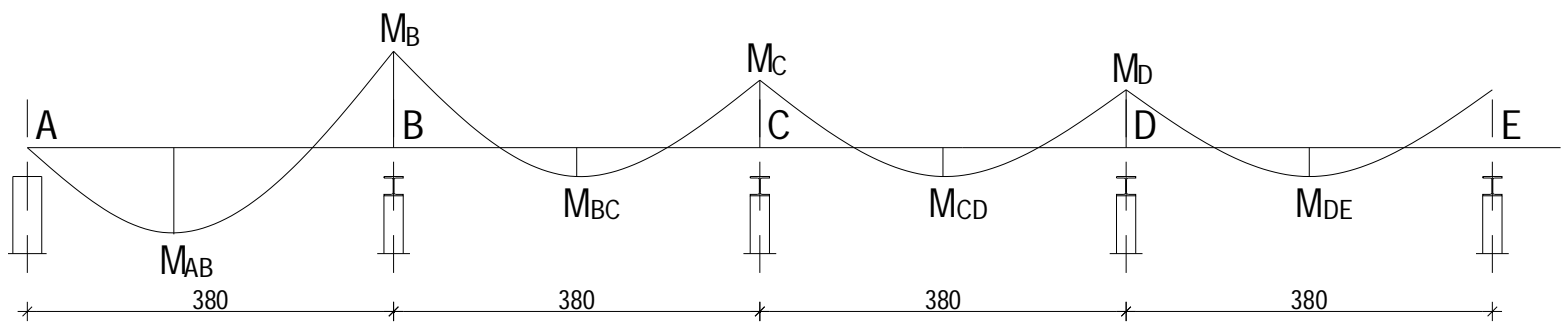

$M_{A B}=0,078 \cdot q_{S d} \cdot 1^{2}=0,078 \cdot 13,7 \cdot 3,8^{2}=15,4 \mathrm{kNm}$

moment u prvom i zadnjem polju

$M_{B C}=0,034 \cdot q_{S d} \cdot l^{2}=0,034 \cdot 13,7 \cdot 3,8^{2}=6,7 \mathrm{kNm}$

moment u ostalim poljima

$M_{B}=-0,106 \cdot q_{S d} \cdot 1^{2}=-0,106 \cdot 13,7 \cdot 3,8^{2}=-21 \mathrm{kNm}$

moment na prvom i zadnjem ležaju

$M_{C}=-0,077 \cdot q_{S d} \cdot 1^{2}=-0,077 \cdot 13,7 \cdot 3,8^{2}=-15,2 \mathrm{kNm}$

moment na ostalim ležajevima

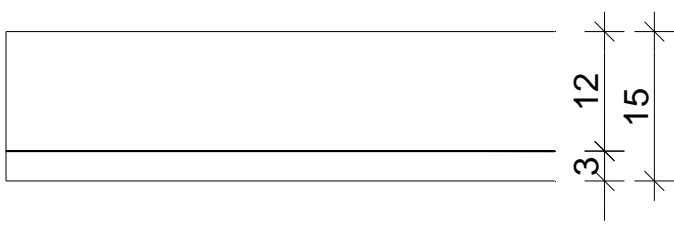

$\mu_{\mathrm{Sd}, \mathrm{AB}}=\frac{1540}{100 \cdot 12^{2} \cdot 2,0}=0,053$ 
$\varepsilon_{\mathrm{c} 2}=1,4 \% ; \varepsilon_{\mathrm{s} 1}=10,0 \% ; \xi=0,123 ; \zeta=0,956$

$A_{s 1, A B}^{I I}=\frac{M_{S d}}{\zeta \cdot d \cdot f_{y d}}=\frac{1540}{0,956 \cdot 12 \cdot 43,5}=3,09 \mathrm{~cm}^{2} / \mathrm{m}$

$A_{s 1,1}=A_{s 1}^{I}+A_{s 1, A B}^{I I}=5,83+3,09=8,92 \mathrm{~cm}^{2} / m$ ukupna armatura u prvom i zadnjem polju

$\mu_{\mathrm{Sd}, \mathrm{BC}}=\frac{670}{100 \cdot 12^{2} \cdot 2,0}=0,023$

$\varepsilon_{\mathrm{c} 2}=0,9 \% ; \varepsilon_{\mathrm{s} 1}=10,0 \% ; \xi=0,083 ; \zeta=0,971$

$A_{s 1, B C}^{I I}=\frac{M_{S d}}{\zeta \cdot d \cdot f_{y d}}=\frac{670}{0,971 \cdot 12 \cdot 43,5}=1,32 \mathrm{~cm}^{2} / \mathrm{m}$

$A_{s 1,2}=A_{s 1}^{I}+A_{s 1, B C}^{I I}=5,83+1,32=7,15 \mathrm{~cm}^{2} / m$ ukupna armatura u ostalim poljima

Armatura na ležaju

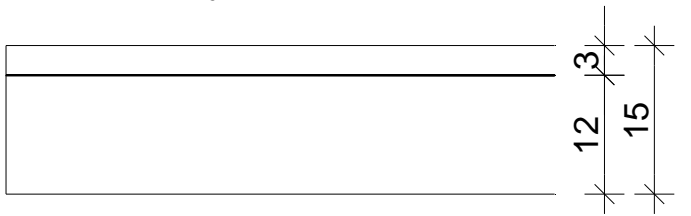

$\mu_{\mathrm{Sd}, \mathrm{B}}=\frac{2100}{100 \cdot 12^{2} \cdot 2,0}=0,073$

$\varepsilon_{\mathrm{c} 2}=1,8 \% ; \varepsilon_{\mathrm{s} 1}=10,0 \% ; \xi=0,153 ; \zeta=0,944$

$A_{s 1, B}=\frac{M_{S d}}{\zeta \cdot d \cdot f_{y d}}=\frac{2100}{0,944 \cdot 12 \cdot 43,5}=4,26 \mathrm{~cm}^{2} / \mathrm{m} \quad$ armatura na prvom i zadnjem ležaju

$\mu_{\mathrm{Sd}, \mathrm{C}}=\frac{1520}{100 \cdot 12^{2} \cdot 2,0}=0,053$

$\varepsilon_{\mathrm{c} 2}=1,4 \% ; \varepsilon_{\mathrm{s} 1}=10,0 \% ; \xi \xi=0,123 ; \zeta=0,956$

$A_{\mathrm{s} 1, \mathrm{C}}=\frac{M_{\mathrm{Sd}}}{\zeta \cdot d \cdot f_{\mathrm{yd}}}=\frac{1520}{0,956 \cdot 12 \cdot 43,5}=3,05 \mathrm{~cm}^{2} / \mathrm{m} \quad$ armatura na ostalim ležajevima

Rezultat proračuna omnia ploča vidljiv je na Slici 10. Budući da su omnia ploče u ovom rješenju nešto većeg raspona, za sve ploče potrebna je mreža R-785 $(010 / 10 \mathrm{~cm})$ koja se u prvom polju dodatno ojačava s po 2 šipke $\varnothing 10$ po rubu svake ploče. Za gornju zonu ploče odabrana je armaturna mreža R-503. 

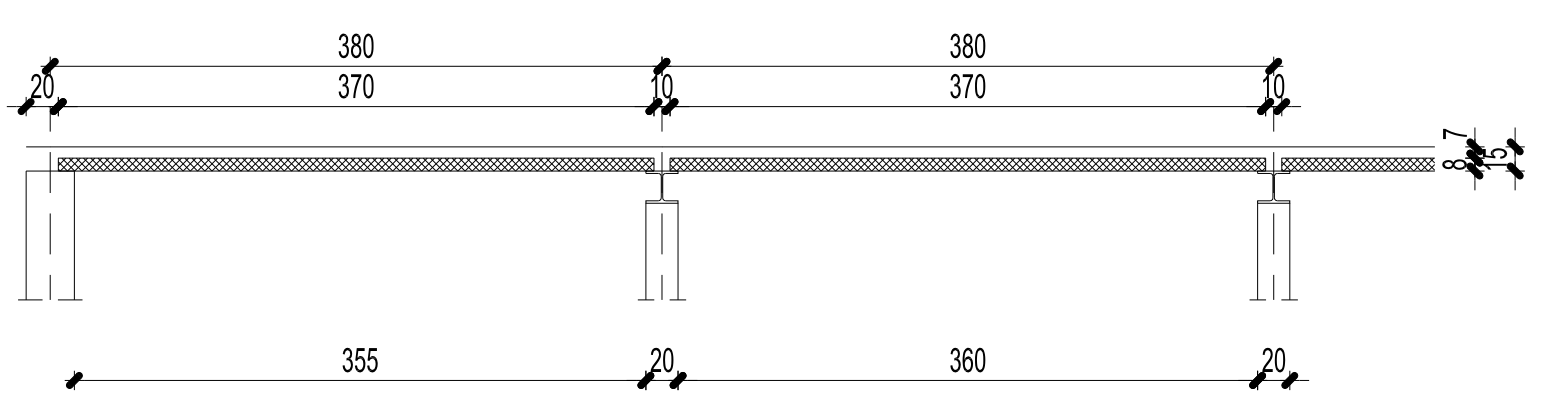

360

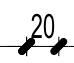

DONJAZONA

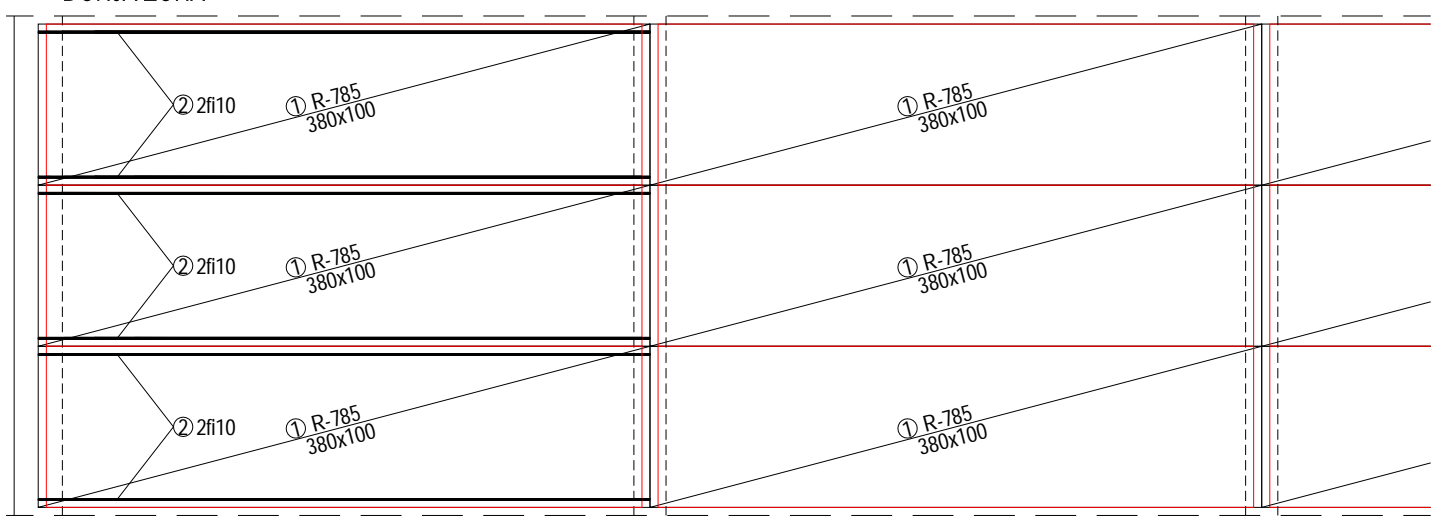

GORNJAZONA

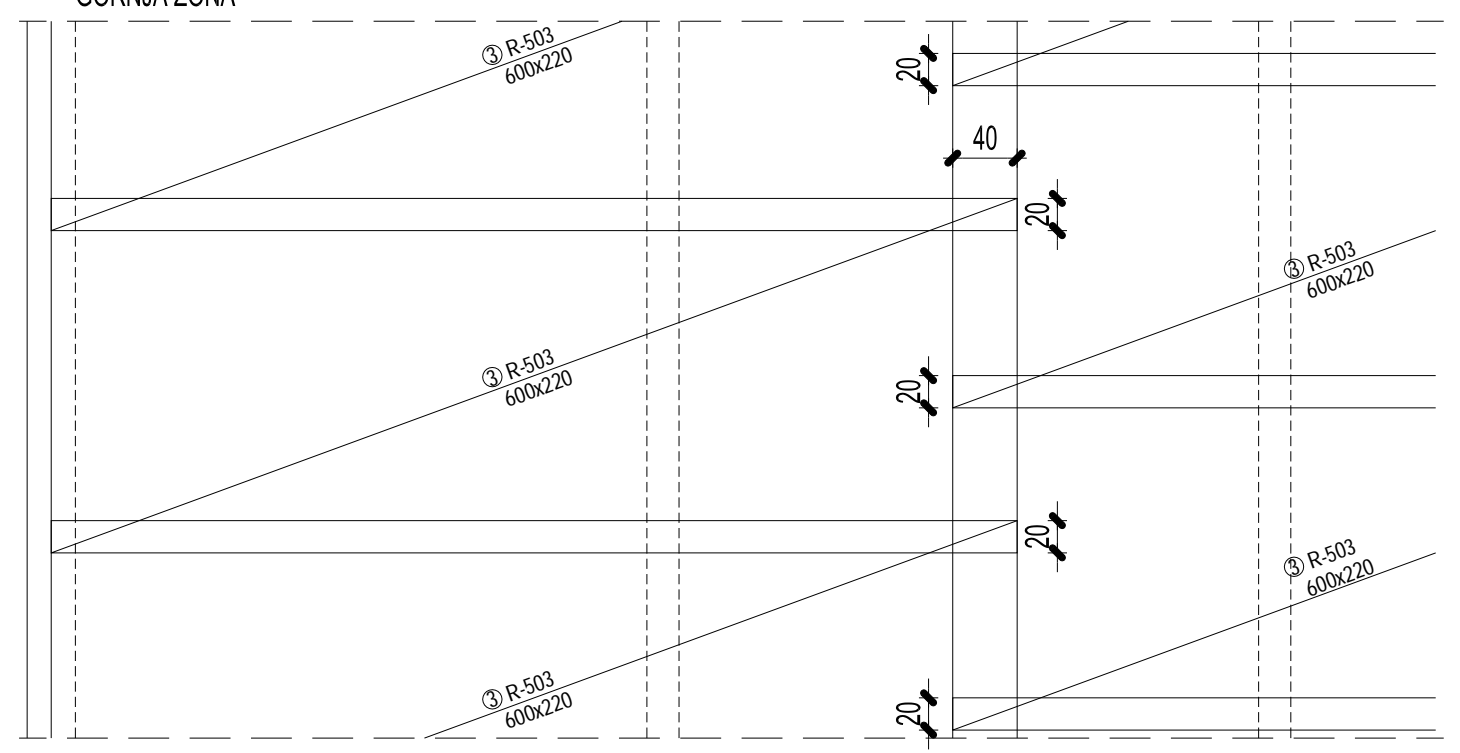

Slika 10 - Odabrana armatura u ploči krova 


\subsection{Proračun prednapetih nosača}

\subsection{Proračun prednapetih nosača}

Poprečni presjek krovnih prednapetih nosača prikazan je na slici 11. Uzdužni presjek prikazan je na slici 12. Krovni nosači su ošupljeni da bi se provukle instalacije klimatizacije. Ošupljenje je izvedeno s dvjema okruglim rupama promjera $75 \mathrm{~cm}$, na položaju prema slici 12.

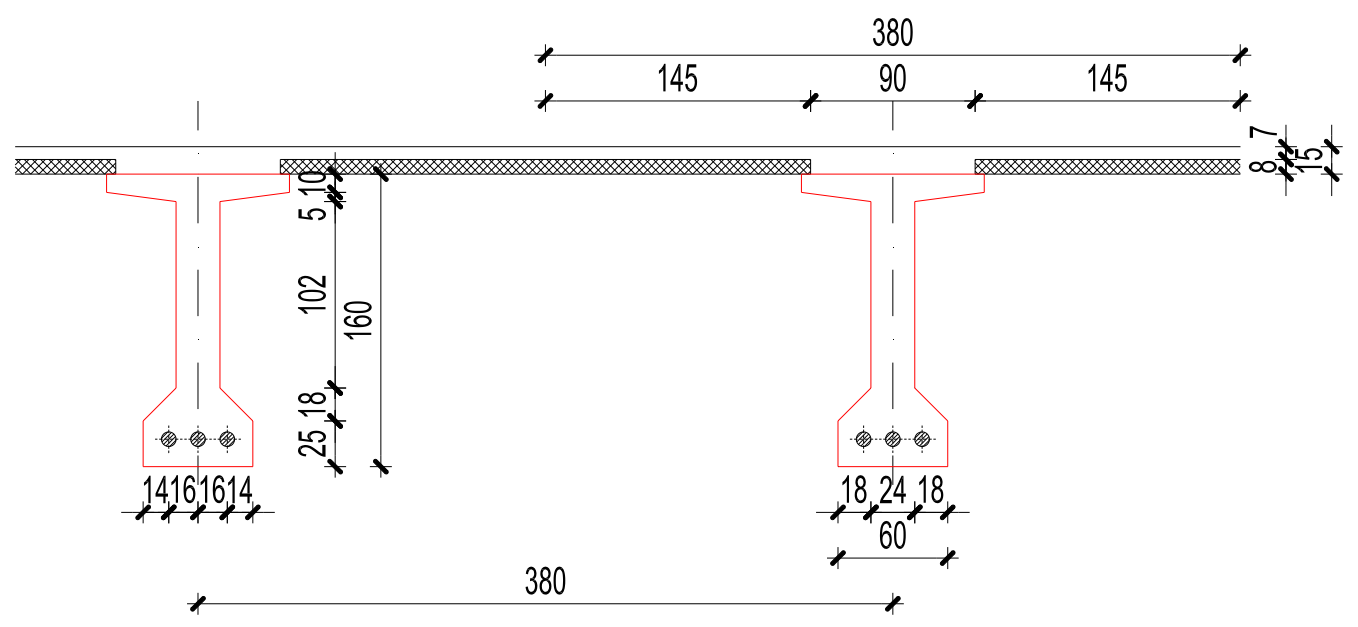

Slika 11 - Poprečni presjek krovnih nosača
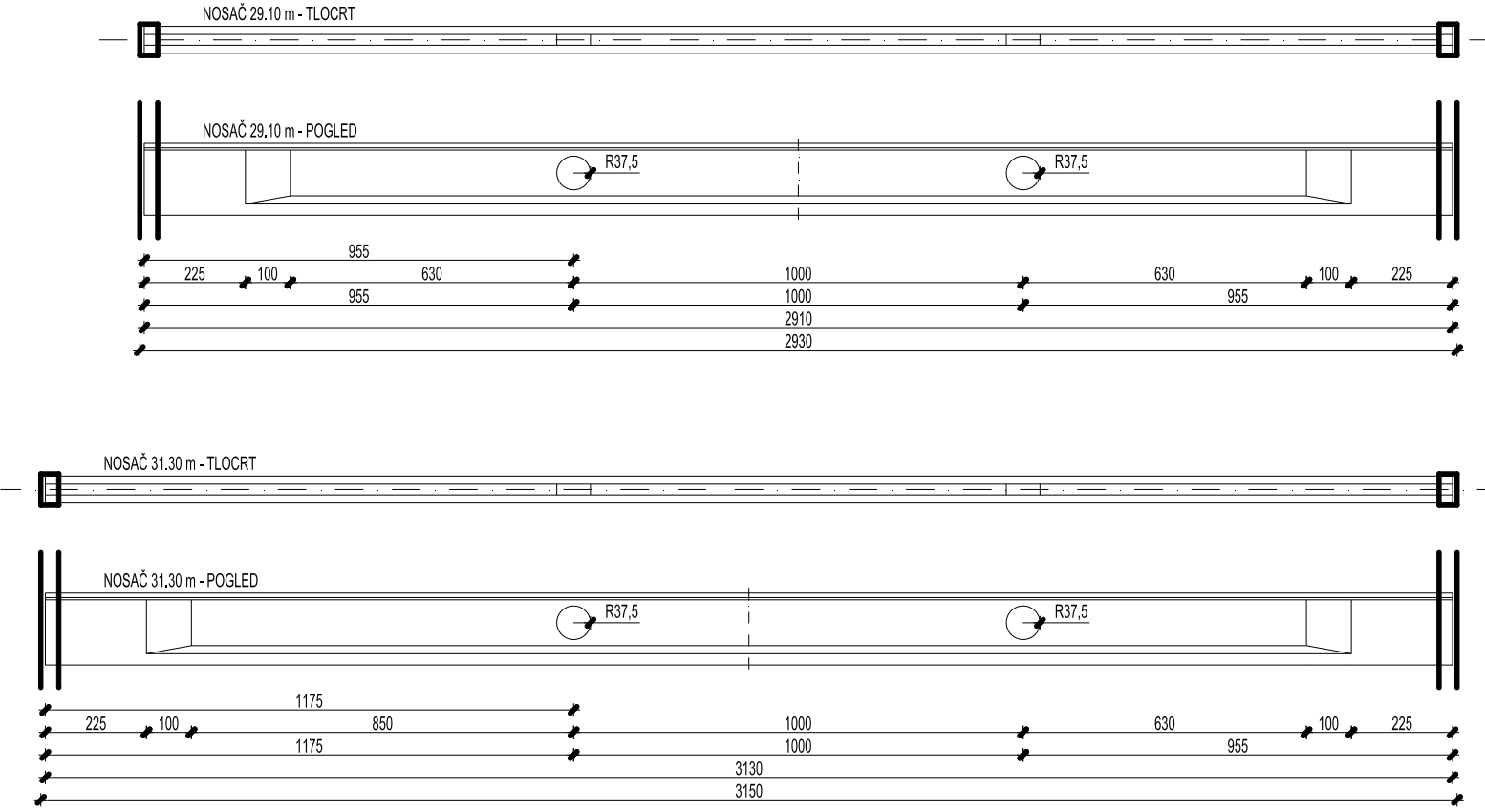

Slika 12 - Uzdužni presjek krovnih nosača

Nosači su također proračunati u tri faze. U nultoj fazi nosač je kontroliran za početno stanje prednapinjanja (opterećenje: samo vlastita težina nosača). U prvoj fazi nosač je kontroliran na opterećenje njegove vlastite težine, te težine omnia ploča i ploča za monolitizaciju. U ovoj fazi nosači su sustava proste grede, a presjek je čisti presjek samog prednapetog nosača. U drugoj fazi napravljen je numerički model, prikazan na Slici 6 , te je on opterećen dodatnim stalnim (slojevi poda) i korisnim opterećenjem. Kontrolirani presjek je prednapeti nosač + ploča. Neki rezultati prikazani su na slici 13. 

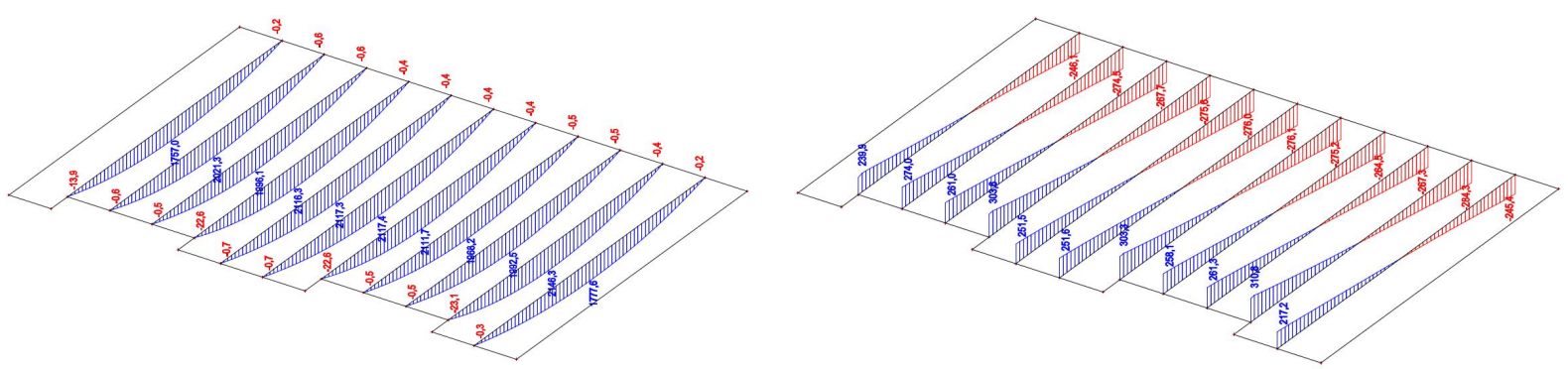

Slika 13 - Neki rezultati numeričkog modela momenti i poprečne sile u nosačima za korisno opterećenje

Kako je napomenuto, nosač je djelomično prednapet, tj. potpuno prednapet za $0,3 \mathrm{Mq}$ (30\% momenta korisnog opterećenja). Ovo je napravljeno zbog toga što je $5,0 \mathrm{kN} / \mathrm{m}^{2}$ traženog korisnog opterećenja na igralištu opterećenje koje će se vrlo rijetko pojaviti. Ostalih 70\% momenta korisnog opterećenja preuzeto je nenapetom armaturom. Sami postupak dimenzioniranja ovdje nije prikazan, a može se naći u [1]. Odabrane natege i nenapeta armatura prikazani su na slikama 14 i 15.
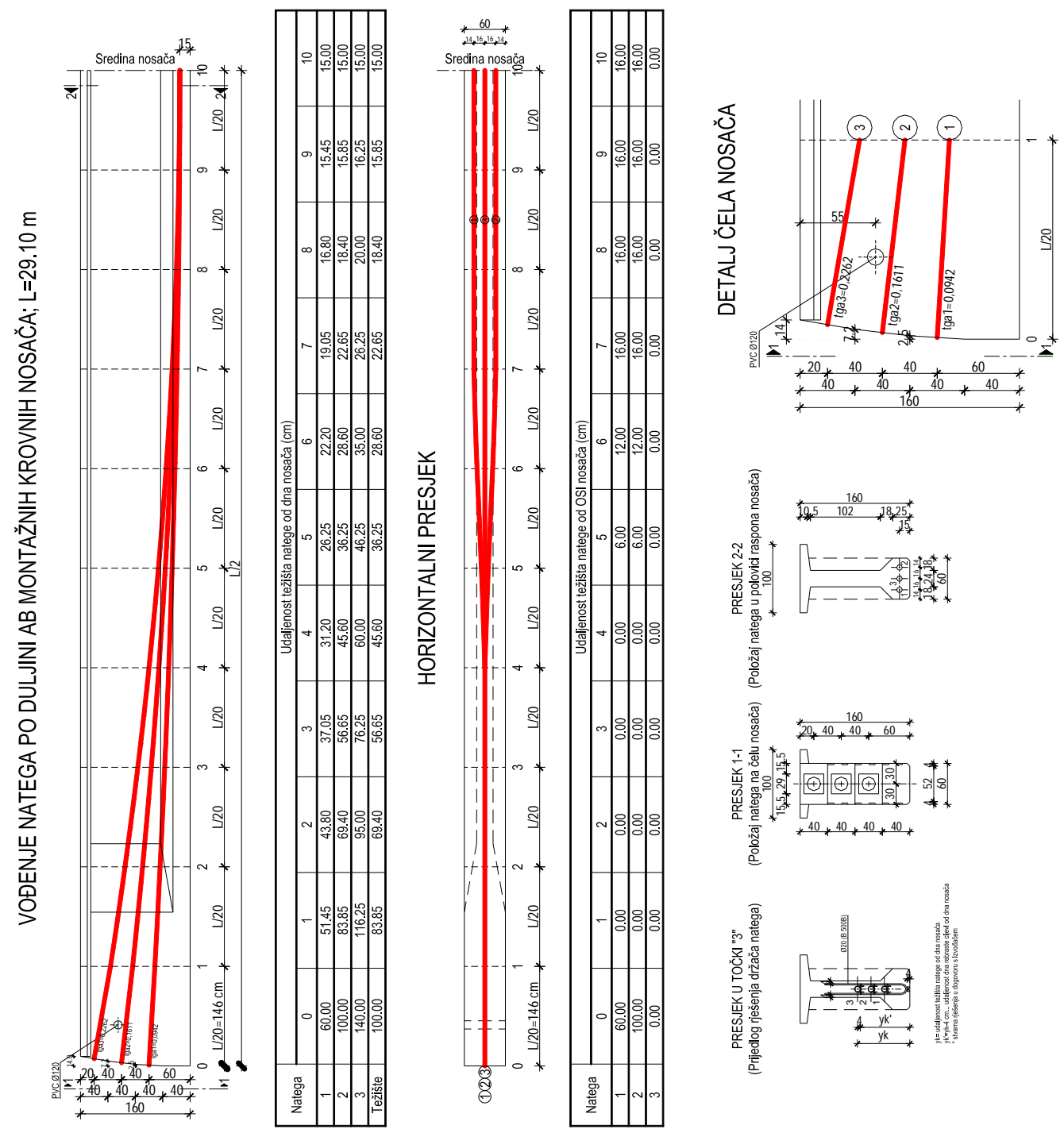

Slika 14 - Položaj natega u nosaču 

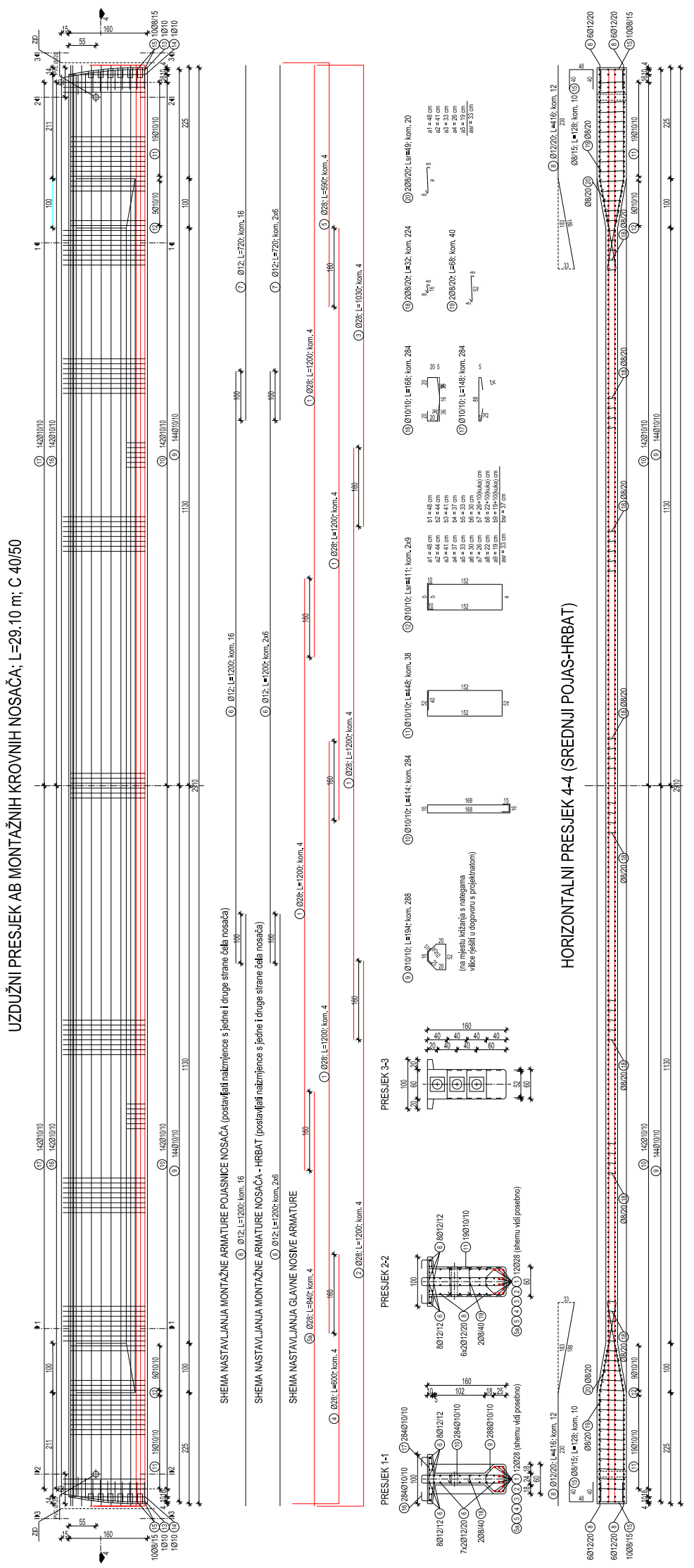

Slika 15 - Položaj nenapete armature nosača 


\subsection{Proračun čelične krovne rešetke}

Na sličan način proračunata je i krovna čelična rešetka. Poprečni presjek čelične rešetke dan je na slici $7, a$ uzdužni presjek na slici 16.
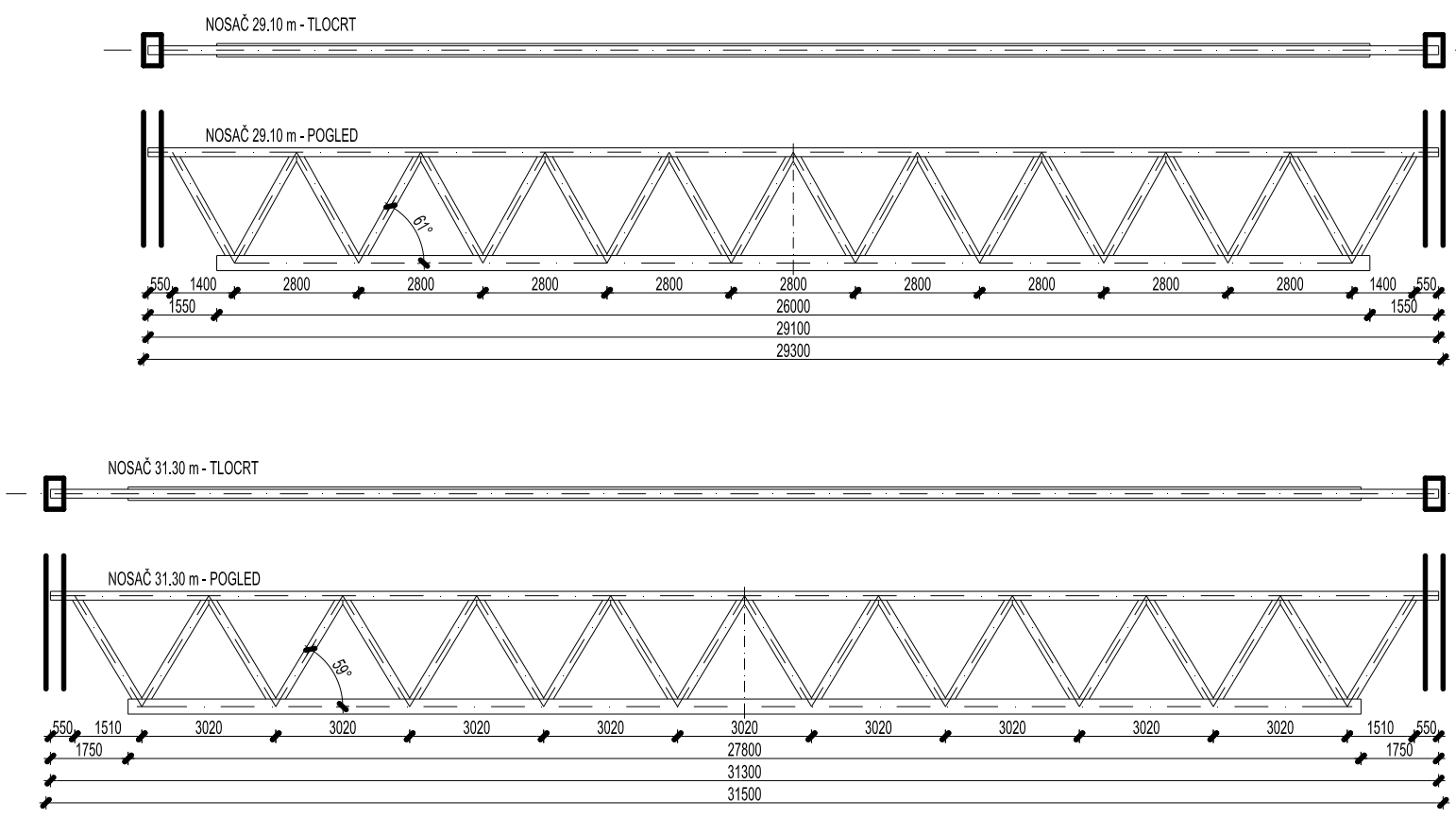

\section{Slika 16 - Uzdužni presjek oba tipa čeličnih rešetki}

Sprezanje čelične rešetke i ploče osigurano je uz pomoć moždanika s glavom, tipa npr. Nelson, od čelika kvalitete S235JR. Moždanici su postavljeni tako da ne smetaju postavljanju omnia ploča. Betonska ploča se tada izvodi lijevanjem na licu mjesta nad omnia pločama.

Model je proračunat u nekoliko faza. Faza 1 je faza montaže. U ovoj fazi konstrukcija je opterećena svojom vlastitom težinom (težina čelične rešetke, omnia ploča i nestvrdnute betonske ploče) i dodatno je kontrolirana na jednoliku promjenu temperature. U 2. fazi konačna konstrukcija je opterećena dodatnim stalnim opterećenjem i s $30 \%$ pokretnog opterećenja, pri čemu je uključeno puzanje betona tlačne ploče. U 3. fazi model je opterećen $s$ ostatkom od $70 \%$ korisnoga opterećenja, bez uključenja puzanja betona.
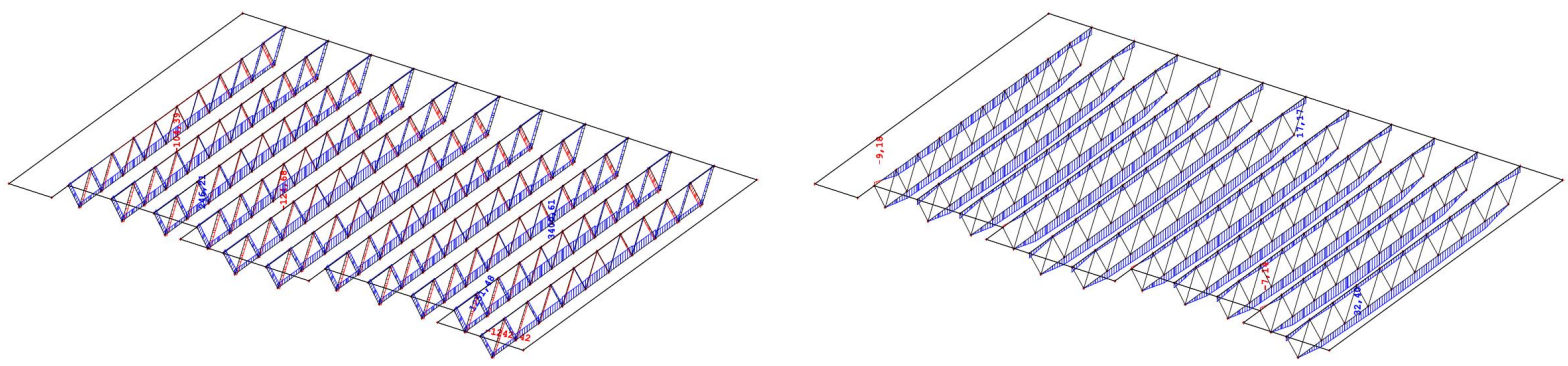

Slika 17 - Neki rezultati numeričkog modela uzdužne sile (lijevo) i momenti (desno) za računsku kombinaciju opterećenja $(1,35 \cdot \Delta g+1,5 \cdot q)$ (sumarno djelovanje faze 2 i faze 3 ) 
Odabrani čelični profili prikazani su na slici 18.

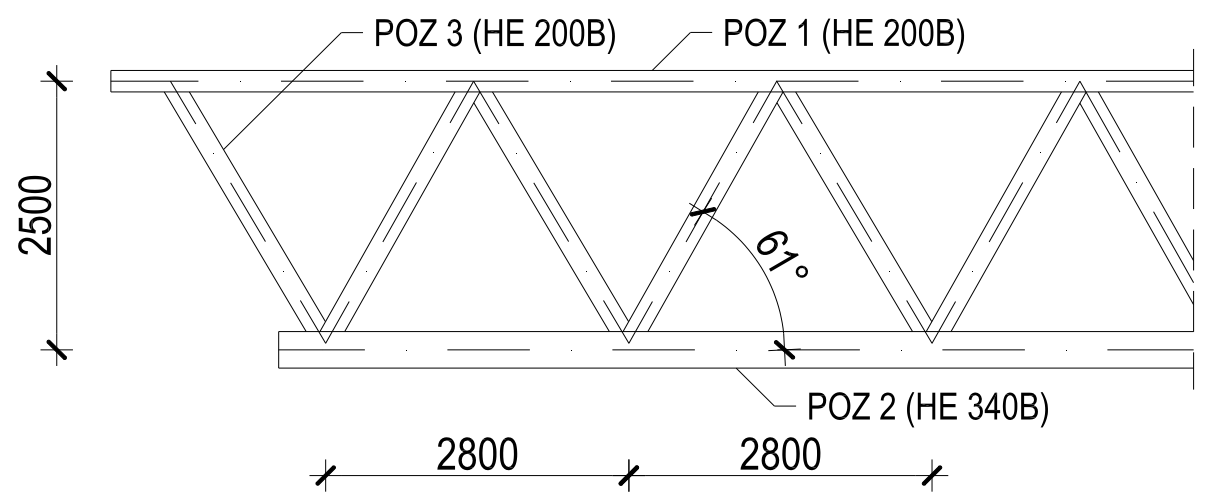

Slika 18 - Odabrani čelični profili rešetke (detalj)

\section{Analiza cijena i zaključak}

Kako je prethodno prikazano, oba rješenja su moguća i funkcionalna u konkretnom slučaju. Rješenje s čeličnom rešetkom zahtijeva veću visinu konstrukcije nego je to slučaj kod prednapetog nosača. U nastavku su u tablici sortirane količine upotrijebljenog materijala te dane neke prosječne cijene.

\begin{tabular}{|c|c|c|c|c|c|c|}
\hline \multirow{2}{*}{$\begin{array}{c}\text { Materijal I } \\
\text { Konst. elem. }\end{array}$} & \multirow{2}{*}{$\begin{array}{c}\text { Jedinica } \\
\text { mjere }\end{array}$} & \multirow{2}{*}{$\begin{array}{c}\text { Jedinična } \\
\text { cijena }\end{array}$} & \multicolumn{2}{|c|}{ Prednapeti nosač } & \multicolumn{2}{|c|}{ Celična rešetka } \\
\hline & & & Količina & Cijena & Količina & Cijena \\
\hline $\begin{array}{l}\text { Omnia ploča - beton, } \\
\text { transport, montaža }\end{array}$ & $\mathrm{m}^{3}$ & $1.200,00$ & 85,42 & $102.504,00$ & 106,56 & $127.872,00$ \\
\hline $\begin{array}{l}\text { Ploča za monolit. - beton s } \\
\text { ugradnjom }\end{array}$ & $\mathrm{m}^{3}$ & 700,00 & 121,12 & $84.780,50$ & 99,98 & $69.982,50$ \\
\hline $\begin{array}{l}\text { Ploča - armatura (savijanje, } \\
\text { ugradnja, vezivanje) }\end{array}$ & $\mathrm{kg}$ & 7,00 & $6.581,79$ & $46.072,52$ & $9.963,25$ & $69.742,76$ \\
\hline Nosač - beton, oplata & $\mathrm{m}^{3}$ & $1.200,00$ & 217,92 & $261.505,20$ & 0,00 & 0,00 \\
\hline $\begin{array}{l}\text { Nosač - čelik sa osnovnom } \\
\text { AKZ zaštitom - } 1 \text { temeljni + } 1 \\
\text { završni premaz) }\end{array}$ & $\mathrm{kg}$ & 16,00 & 0,00 & 0,00 & $100.320,83$ & $1.605 .133,28$ \\
\hline $\begin{array}{l}\text { Nosač - kablovi, pripadajuće } \\
\text { kotve, injekcijska masa }\end{array}$ & $\mathrm{kg}$ & 20,00 & $11.931,70$ & $238.634,00$ & 0,00 & 0,00 \\
\hline $\begin{array}{l}\text { Nosač - armatura (savijanje, } \\
\text { ugradnja, vezivanje) }\end{array}$ & $\mathrm{kg}$ & 7,00 & $51.535,00$ & $360.745,00$ & 0,00 & 0,00 \\
\hline & & & JPNO (Kn): & $1.094 .241,22$ & & $1.872 .730,54$ \\
\hline
\end{tabular}

Vidljivo je da je u danom slučaju optimalan prednapeti nosač i to zbog dva razloga: prvi što je cijena njegove izrade nešto manje od dvije trećine cijene čelične rešetke, a drugi što se njime postiže niža konstrukcija (jer bi u cijenu čelične rešetke trebalo uključiti i cijenu nešto viših zidova dvorane, ili izraditi robusniju čeličnu rešetku koja bi poskupila samo rješenje).

Dakako, ovakvo gledanje na problem je pomalo jednostrano, jer u ukupnu cijenu bi valjalo uključiti i cijenu transporta, montaže i manipulacije koja bi uključivala, npr., i cijenu postavljanja. Vidljivo je da je prosječna težina čelične rešetke oko $100 / 9=11 \mathrm{t}$, a prosječna težina prednapetog nosača oko $(218 \cdot 2,4+12+51) / 9=62 \mathrm{t}$, što čini znatnu razliku u veličini dizalice koja je potrebna za montažu. U prilog tome ide i činjenica da je potencijalni izvođač već razmatrao rješenje s čeličnom rešetkom zbog teškog pristupa objektu. 


\section{Literatura}

[1] Ćurković, G.: Proračun dogradnje dvorane Stobreč, diplomski rad, Sveučilište u Splitu, Fakultet građevinarstva, arhitekture i geodezije, Split, 2011.

[2] Dogradnja Osnovne škole Stobreč, glavni projekt, Arhitektonski biro Ante Kuzmanić" d.o.o., Split, T.D. 06/07LD, 2007

[3] HRN ENV 1991-1 - Eurokod 1: Djelovanja na konstrukcije - Dio 1-1: Opća djelovanja: Gustoće, vlastite težine, korisna opterećenja

[4] HRN ENV 1992-1 - Proračun betonskih konstrukcija - Dio 1-1: Opća pravila i pravila za zgrade

[5] HRN ENV 1994-1 - Proračun spregnuth konstrukcija čelik-beton - Dio 1-1: Opća pravila i pravila za zgrade

[6] HRN ENV 1998-1 - Proračun konstrukcija na potres - Dio 1-1: Opća pravila, seizmička djelovanja i pravila za zgrade 